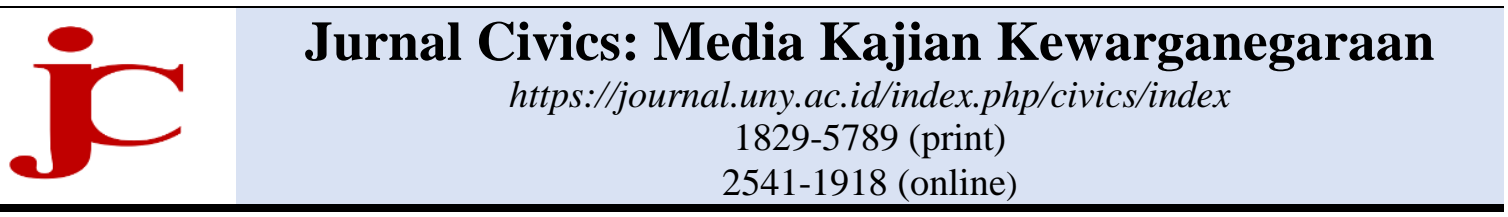

\title{
Teachers and technology: The perspective of digital citizenship
}

\author{
Rini Triastuti a, ${ }^{*}$ \\ a UNS, PPKn, Surakarta, Indonesia \\ ${ }^{1}$ rinitriastuti@staff.uns,ac.id* \\ *korespondensi penulis
}

\begin{tabular}{ll}
\hline \multicolumn{2}{l}{ Informasi Artikel } \\
\hline Sejarah artikel: & \\
Diterima & $: 09-10-2018$ \\
Revisi & $: 02-03-2019$ \\
Dipublikasikan & $: 31-03-2019$ \\
\hline
\end{tabular}

\section{Kata kunci:}

Guru

Teknologi

Kewarganegaraan digital \begin{abstract}
ABSTRAK
Perkembangan teknologi informasi dan komunikasi telah menghasilkan beragam produk baik dalam bentuk hardware dan software. Produk tersebut telah menawarkan berbagai kemudahan bagi penggunanya. Salah satu contoh di bidang komunikasi. Saat ini komunikasi dapat dilakukan setiap saat tanpa dibatasi oleh jarak dan waktu. Berbagai kemudahan yang ditawarkan bagi penggunanya membuat mereka sangat tergantung pada teknologi. Bahkan saat ini manusia tidak hanya berada dalam dunia nyata saja namun juga dalam dunia maya. Tulisan ini bermaksud menggambarkan karakteristik kewarganegaraan guru-guru pendidikan pancasila dan kewarganegaraan. Pendekatan yang digunakan adalah deskriptif kualitatif. Instrumen yang digunakan dalam penelitian adalah angket, wawancara dan studi pustaka. Data menunjukkan bahwa guru-guru merupakan warga digital dan digital immigrant.

ABSTRACT

The rapid growth of information and communication technology has produced various forms of products in the form of hardware and software. These products have offered various conveniences for its users. One example is in the field of communication. Currently, communication can be done in real time without being blocked by distance and time. The various facilities provided to its users make them very dependent on technology. Even today humans do not only exist in the real world but in the virtual world. This paper is intended to describe the characteristics of digital citizenship for civic education teachers. The method used is descriptive qualitative. This study uses questionnaires, interviews and literature studies. The results show that teachers are digital citizens and digital immigrant.
\end{abstract}

Keywords:

Teacher

Technology

Digital Citizenship

\section{Copyright $@ 2018$ Rini Triastuti}

\section{Introduction}

Information and communication technology is growing rapidly in recent decades. This has had an impact on all aspects of life; even now, we cannot be separated from the technology because every day we are exposed to such technologies as sending or receiving an e-mail, sending messages through social media, searching for information on the internet and so on. Technology has brought convenience and usefulness to daily activities.

Since the Indonesian government developed internet infrastructure in the 1980s the number of internet users has increased from year to year. According to APJII (2015), internet users in Indonesia in 2010 amounted to 42 million with a population of 238.5 million. This shows that the penetration is $17.6 \%$. Then in 2011, internet users increased to 55 million with a population of 242 million, which means there was a penetration of $22.7 \%$. The following year internet users became 63 million with a population of 245.5 million, which means there was a penetration of $24.23 \%$.In 2013 internet users increased to 71.2 million with a population of 248.9 million, which means there was a penetration 
of $28 \%$. Then in 2014 , internet users became 88.1 million with a population of 252.4 million, which means there was a penetration of $34.9 \%$.

The McArthur Foundation Research Network on Participatory Politic survey results that $41 \%$ of youth aged 15 to 25 years have participated in new political groups online, wrote and disseminated blogs about political issues and political videos on their social media (Kahne \& Middaugh, 2012). This shows the power of digital media to influence the political participation of young citizens. This condition is reinforced by Martens \& Hobbs (Martens \& Hobbs, 2015) research that there is a relationship between media literacy and increasing knowledge and civic engagement of young citizens and contributing to their civic engagement as adults

The majority of internet users in Indonesia is between 18-25 years old, which is almost half of the total number of internet users in Indonesia, which is $49 \%$ (APJII, 2015, p. 3). This describes that the segment of internet users in Indonesia is those who belong to the digital native category.

Digital native will be able to adapt very quickly and easily to the presence of new technologies. This is evident when students are quickly able to operate the cell phone they just met. That is very natural because this is their world, the digital world. As a teacher and migrant in a particular digital era, you must adjust, adjust the way they educate them according to the way they live in the digital era, and prepare them to face the challenges of the future.

Characteristics of students in using information and communication technology outline the results of the study show the following results:

a. Utilization of computers/notebooks: the majority of students use computers/notebook with a frequency of once a week with a duration more than 12 hours, even though only $48.93 \%$ have their own computers/notebooks while the rest use computers that are in school or on the internet. Meanwhile, computer programs that are often used by students are MS Word and other programs such as photo-shop and coral draw. The ability to use a computer application is obtained without participating in a special course /training but by self-study independently.

b. Use of mobile phones: the results of the study show that the majority of students access the internet every day with the duration more than 1-2 hours while the majority of the access goals are communicated. Meanwhile, the majority of students use mobile phones as a device to access the internet using wifi.

c. Internet usage: the results show that the majority of students have social media accounts that are accessed every day with a duration between 0-1 hours. Meanwhile, the device used by the majority of students to access social media is a mobile phone. The majority of students use Android-based smartphones and the majority of students start having mobile phones since sitting in junior high school (Triastuti, 2017; Triastuti, Budimansyah, \& Sapriya, 2016).

On the other hand, adults are also users of information and communication technology. But whether they have the same character as teenagers in using technology or different is something interesting to study.

\section{Method}

This study used the descriptive qualitative method. The instruments used to collect data are questionnaires, interviews and literature studies. The location of this study is Surakarta, Central Java Province. Triangulation used is the triangulation method. The sample of this study was 12 civics education teachers in Surakarta City, Central Java Province. This study involved 5 schools.

\section{Results and Discussion \\ Result}

The trend of increasing users of information and communication technology from year to year showing proves that the benefits offered by these technologies are 
directly proportional to the needs of today's society. Society cannot be separated from information and communication technology in daily life. The following data will illustrate the characteristics of digital citizenship teachers in the use of information and communication technology. The data details the habits of teachers to access information and communication technology, their frequency, duration, location, tools, programs, participation in courses/training and communication. Data shows that:

a. The ownership of a computer or notebook

Table 1 Ownership of a computer or notebook

\begin{tabular}{lcc}
\hline \multicolumn{1}{c}{ Information } & Yes & No \\
\hline $\begin{array}{l}\text { have a compr or } \\
\text { notebook }\end{array}$ & 12 & - \\
\hline
\end{tabular}

Data shows that all teachers have a computer or notebook. It means that they are able to access information and communication technology. They don't have problems with the hardware because it has been available.

b. The frequency of accessing a computer or notebook

Table 2 Frequency of accessing a computer or notebook

\begin{tabular}{lc}
\hline \multicolumn{1}{c}{ Information } & Quantity \\
\hline Every day & 10 \\
Once a week & 2 \\
Once a month & - \\
\hline
\end{tabular}

The existence of hardware has an impact on teachers in using it. The majority of teachers' about $83.33 \%$ access technology every day.

c. The duration of accessing a computer or notebook

Table 3 Duration of accessing a computer or notebook

\begin{tabular}{lc}
\hline \multicolumn{1}{c}{ Information } & Quantity \\
\hline $0-1$ hour & 3 \\
$1,01-2$ hour & 2 \\
$2,01-3$ hour & 5 \\
$3,01-4$ hour & 1 \\
More than 4 hour & 1 \\
\hline
\end{tabular}

The use of hardware by teachers shows that almost half of the sample about $41.6 \%$ of teachers using information and communication technology for 2.01-3 hour.

d. The location of accessing a computer or notebook

Table 4 Location of accessing a computer or netbook

\begin{tabular}{lc}
\hline \multicolumn{1}{c}{ Information } & Quantity \\
\hline Home & 10 \\
school & 2 \\
Computer rental & - \\
Internet cafe & - \\
\hline
\end{tabular}

Location commonly used by teachers to use technology shows that the majority of teachers accessing computers or notebooks at home about $83.33 \%$.

e. The programs accessed

Table 5 Programs accessed

\begin{tabular}{lc}
\hline \multicolumn{1}{c}{ Information } & Quantity \\
\hline MS Word & 11 \\
Excel & - \\
Powerpoint & 1 \\
Moviemaker & - \\
Others & - \\
\hline
\end{tabular}

The teacher's habit of using software shows the fact that the majority of teachers about $91.6 \%$ access MS word programs when using a computer or notebook.

f. Participation in courses/training

Table 6 Participation in courses/training

\begin{tabular}{ccc}
\hline Information & Yes & No \\
\hline Take courses / training & 9 & 3
\end{tabular}

The ability of teachers to use technology is supported by their participation in a course or training. This is based on the fact that the majority or $75 \%$ of teachers takes courses to be able to operate a computer/notebook.

g. The location of accessing the internet

Table 7 location accessing the internet

\begin{tabular}{lc}
\hline \multicolumn{1}{c}{ Information } & Quantity \\
\hline Home & 9 \\
School & 3 \\
Internet cafe & - \\
Mall & - \\
\hline
\end{tabular}

The need for the internet can be fulfilled anywhere. Similarly, the data sample shows that the majority of teachers 
about $75 \%$ have the habit of internet access at home. This is done when they are not teaching so that it does not interfere with the learning process.

h. Internet access duration

\begin{tabular}{lc}
\multicolumn{2}{c}{ Tabel 8 Internet access duration } \\
\hline \multicolumn{1}{c}{ Information } & Quantity \\
\hline $0-1$ hour & 5 \\
$1,01-2$ hour & 3 \\
$2,01-3$ hour & 3 \\
$3,01-4$ hour & - \\
More than 4 hour & 1 \\
\hline
\end{tabular}

The teacher's habit of accessing the internet shows that almost half of $41.6 \%$ of teachers access the internet with a duration between 0-1 hours.

i. The frequency of accessing the internet Table 9 Frequency of accessing the internet

\begin{tabular}{lc}
\hline \multicolumn{1}{c}{ Information } & Quantity \\
\hline Once an hour & - \\
Once a day & 8 \\
Once a week & 4 \\
Once a month & - \\
\hline
\end{tabular}

Various information offered by the internet makes our lives closer to the internet. Our needs for various information will always guide us to access the internet. Likewise, the need for teachers on the internet shows that the majority of samples accessing the internet every day is about $66.6 \%$

j. Internet access tool

Table 10 Internet access tool

\begin{tabular}{lc}
\hline \multicolumn{1}{c}{ Information } & Quantity \\
\hline computer & 3 \\
notebook & 6 \\
tablet & 1 \\
Mobile phone & 2 \\
\hline
\end{tabular}

The teacher's habit of accessing the internet cannot be separated from the tools they use to access it. Data shows that half of the samples access the internet using a notebook.

$\mathrm{k}$. The purpose of accessing the internet

Table 11 The purpose of accessing the internet

\begin{tabular}{lc}
\hline \multicolumn{1}{c}{ Information } & Quantity \\
\hline Look for materials to do the task & 7 \\
communication & 3 \\
Shopping & - \\
\hline
\end{tabular}

\begin{tabular}{ll}
\hline Gaming & - \\
News & - \\
Other & 2 \\
\hline
\end{tabular}

The use of the internet by teachers cannot be separated from their various needs when accessing the internet. The data show that the majority of teachers access the internet to find the material that is used for assignments that are about $58.3 \%$. Meanwhile, only $25 \%$ use it to communicate and $16.6 \%$ access the internet for other purposes. Thus they access the internet in order to support the work.

1. Internet access channel

Tabel 12 Internet access channel

\begin{tabular}{lc}
\hline \multicolumn{1}{c}{ Information } & Quantity \\
\hline Wifi & 7 \\
Modem & 1 \\
Mobile phone & 3 \\
other & 1 \\
\hline
\end{tabular}

Their habit of accessing the internet cannot be separated from what channels are used to access the internet. Because the availability of these channels determines the opportunity for them to access the internet. The data show that is about $58.33 \%$.

m. The ownership of social media accounts

Table 13 Ownership of social media

\begin{tabular}{|c|c|c|}
\hline accoun & & \\
\hline Information & Yes & No \\
\hline Have a social media account & 12 & - \\
\hline
\end{tabular}
technology for communication are visible from the social media they have. Data shows that all the teachers have social media accounts.

n. The frequency of accessing social media

Table 14 Frequency of accessing social media

\begin{tabular}{lc}
\hline \multicolumn{1}{c}{ Information } & Quantity \\
\hline Every hour & 2 \\
Every day & 9 \\
Every week & - \\
Every month & 1 \\
\hline
\end{tabular}

The majority of teachers have a habit of accessing social media every day. This is supported by data that about $75 \%$ of 
teachers access social media every day. It seems that they need social media as a medium of communication.

o. The tool used to access social media

Table 15 The tool used to access social media

\begin{tabular}{lc}
\hline Information & Quantity \\
\hline computer & - \\
notebook & 5 \\
Tablet & 6 \\
Mobile phone & 1 \\
\hline
\end{tabular}

The teacher's habit of accessing social media is supported by the availability of available tools. The fact shows that the majority of teachers use tablets / mobile phones to access social media about 58.3\%.

p. The mobile phone system which used

Table 16 Mobile phone system which

\begin{tabular}{lc}
\multicolumn{2}{c}{ used } \\
\hline \multicolumn{1}{c}{ Information } & Quantity \\
\hline Android & 10 \\
Blackberry & 1 \\
iPhone & - \\
Another smartphone & 1 \\
\hline
\end{tabular}

The majority of teachers has used mobile phones belonging to the category of smartphones. This is supported by data that $83.3 \%$ of samples use an Android-based mobile phone. Mobile phones based on smartphones are capable of being used to make telephone calls and send short messages can also be used to access the internet or various applications offered. The selection of teachers on the mobile phone system shows that their needs are not only to make telephone and short messages call but also to access the internet and various applications.

\section{Discussion}

Today's digital world has touched all aspects of life. The internet world connects everyone and provides everything but no one is responsible when an error occurs when using the internet and the error goes back to people who use the internet (Scobey, 2001). The internet is a technology that is neutral, free, open and unregulated, meaning that we are all connected, but no one is responsible. In other words, the internet is a democracy, but without a constitution (Friedman, 1999; Scobey, 2001).

The high growth of the internet and smartphones in Indonesia is not matched by a broad understanding of digital literacy. The technology faces a challenging transition. In the internet era, information flows continuously through social media, group chat, and news channels and cannot digest this information completely and correctly, but has a strong desire to immediately share it with others (Daily Social, 2018). Unfortunately, some information can bring many interpretations and points of view. Some interpretations can cause misunderstandings. In Indonesia, such cases are easy to find, most visible in the political area.

Digital citizenship can be defined as behavioral norms with regard to the use of technology. More briefly said that digital citizenship is the ability to participate in online societies (Mossberger, Tolbert, \& McNeal, 2008). Digital citizenship also means the ability to use technology competently; interpret and understand digital content and assess its credibility; make, research, and communicate with the right tools; think critically about the ethical opportunities and challenges of the digital world; make safe, responsible and respectful online choices (Isman \& Gunggoren, 2014). Thus, the keywords of some of the definitions above are the existence of knowledge and skills to use technology appropriately in the digital world, managing risk and utilizing the participatory opportunities it offers ((Partnership for 21st Century Skills, 2006) While their digital citizens use the Internet regularly and effectively every day ((Mossberger et al., 2008). Teachers can access information and communication technology, both hardware and software. This is in line with one of Ribble, Bailey, \& Ross (2004), digital citizenship elements, namely digital access.

The regular program used by teachers is only the program to support their work, MS Word. This is supported by data that the majority of teachers access the internet to find material for their duties. Thus the ability of teachers is only limited to programs that are 
commonly used. This is in line with the digital immigrant category (Prensky, 2001a, 2001b, 2011; Ribble, 2011)

Teachers need special guidance to be able to run existing programs either through courses or training. Management must support is important for improving teacher digital competencies and integrating them into teacher education (Inan \& Lowther, 2010; Kopcha, 2012). Very few teachers can learn by themselves. This is in line with the views of the Ribble et al (2004) and Prensky (2001a, 2001b, 2011) which state that digital natives have digital instincts so that they can adapt to new technologies without following a specific training/guidance. Instead, digital immigrants need to get special guidance in order to be able to master the technology. Teachers need special guidance to be able to run existing programs either through courses or training. Very few teachers can learn by themselves. This is in line with the views of the Ribble and Bailey (2007) and Prensky (2001a, 2001b, 2009) which state that digital natives have digital instincts so that they can adapt to new technologies without following a specific training/guidance. Instead, digital immigrants need to get special guidance in order to be able to operate the technology.

The majority of teachers accessing can access the internet every day. This is supported by the data of the majority of teachers using smartphones and accessing social media accounts every day. This is in accordance with Mossberger, Tolbert, McNeal (2008) view of digital citizens. Thus, it can be seen that teachers are digital citizens with immigrant digital characters.

\section{Conclusion}

The explanation above has shown the characteristics of digital citizenship of civic education teachers. Teachers are digital citizens with immigrant digital characters. This can be seen from the following: the ability to access the internet every day as shown by the frequency of teachers accessing social media every day and Android-based mobile phones. The mobile phone system is included in the category of smartphones so that it is connected to the network in real time. While digital immigrants appear from the teacher's ability to use software such as MS word that needs to be given training specifically and teachers only use software related to their work while other programs do not matter. While students are digital citizens with digital native characters. This can be seen from: students' ability to access technology is obtained independently without special training. They have the ability to use this technology by conducting their own trials. Programs controlled by students are more varied according to their interests. Based on the characteristics of the student, the teacher should adjust to the characteristics of students in learning.

\section{Reference}

APJII. (2015). Profil Pengguna Internet Indonesia 2014. Jakarta.

Daily Social. (2018). Hoax distribution through digital platforms in Indonesia 2018. Retrieved from https://dailysocial.id/post/laporandailysocial-distribusi-hoax-di-media-sosial2018

Friedman, L. T. (1999). Judgment not included. New Yorks Times.

Inan, F. A., \& Lowther, D. L. (2010). Laptops in the K-12 classrooms: Exploring factors impacting instructional use. Computers and Education, 55(3), 937-944. https://doi.org/10.1016/j.compedu.2010.04. 004

Isman, A., \& Gunggoren, O. C. (2014). Digital citizenship. TOJET: The Turkish Online Journal Od Education Technology, 13(1), 73-77.

Kahne, J. E., \& Middaugh, E. (2012). Digital media shapes youth participation in politics. Phi Delta Kappan, 94(3), 52-56. https://doi.org/10.1177/0031721712094003 12

Kopcha, T. J. (2012). Teachers' perceptions of the barriers to technology integration and practices with technology under situated professional development. Computers and Education, 59(4), 1109-1121. https://doi.org/10.1016/j.compedu.2012.05. 
014

Martens, H., \& Hobbs, R. (2015). How media literacy supports civic engagement in a digital age. Atlantic Journal of Communication, 23(2), 120-137. https://doi.org/10.1080/15456870.2014.961 636

Mossberger, K., Tolbert, C. J., \& McNeal, R. S. (2008). Digital citizenship. The internet, society, and participation. Cambridge, Massachusetts London, England: The MIT Press.

Partnership for 21st Century Skills. (2006). 21st century learning environments. Washington DC: Partnership for 21st Century Skills. https://doi.org/10.1787/9789264006508-en

Prensky, M. (2001a). Digital Natives, Digital Imigrants. Part II: Do they really think differently? On the Horizon, 9(6).

Prensky, M. (2001b). Digital natives, digital immigrants. On the Horizon, 9(5), 102-116.

Prensky, M. (2011). H. sapiens digital : From digital immigrants and digital natives to digital wisdom. Innovate, 5(3).

Ribble, M. (2011). Digital Citizenship in Schools. An Excerpt from Digital Citizenship in Schools 2nd Edition, 3777, 1-32. https://doi.org/10.1111/j.14678535.2012.01378_9.x

Ribble, M., Bailey, G. D., \& Ross, T. W. (2004). Digital Citizenship: Addressing appropriate technology behavior (Vol. 32). https://doi.org/10.1002/asi.20906

Scobey, D. (2001). The specter of citizenship. Citizenship Studies, 5(1), 11-26. https://doi.org/10.1080/1362102002002516 9

Triastuti, R. (2017). Model pengembangan pendidikan kewarganegaraan bagi upaya pembinaan kewarganegaraan digital (digital citizenship) melalui pemanfaatan teknologi informasi dan komunikasi di sekolah. Universitas Pendidikan Indonesis.
Triastuti, R., Budimansyah, D., \& Sapriya, S. (2016). Digital citizenship students viewed from digital commerce aspect. In 1st Global Conference on Business, Management and Entreupreuneurship (GCBME-16) (Vol. 15, pp. https://doi.org/10.2991/gcbme-16.2016.169 